\title{
Sonic identity and audio branding elements in Spanish radio advertising
}

\author{
Estrella Barrio Fraile \\ Ana María Enrique Jiménez \\ María Luz Barbeito Veloso \\ Anna Fajula Payet \\ Universitat Autònoma de Barcelona. Facultat de Ciències de la Comunicació \\ estrella.barrio@uab.cat \\ anamaria.enrique@uab.cat \\ mariluz.barbeito@uab.cat \\ anna.fajula@uab.cat
}

Submission date: June 2020

Accepted date: December 2020

Published in: December 2021

Recommended citation: Barrio Fraile, E.; EnRIQUe JimÉnez, A.M.; BARBEITO Veloso, M.L. and Fajula PaYeT, A. (2021). "Sonic identity and audio branding elements in Spanish radio advertising”. Anàlisi: Quaderns de Comunicació i Cultura, 65, 103-119. DOI: <https://doi. org/10.5565/rev/analisi.3330>

\begin{abstract}
The emotional potential of sound is an excellent resource for companies and institutions seeking to test new ways of communicating with their stakeholders through the senses. However, there are still few organizations that include sound as a conveyer of their corporate identity. Audio branding aims to expand the contact points with audiences by incorporating sound elements that facilitate the recognition of the brand's values. This research attempts to understand the use that corporations make of sound as a communication tool and to evaluate its presence, but above all it wants to find out if this use is due to a strategic approach or if it is a specific decision marked by the temporality of advertising campaigns. For this reason, in this paper we have taken the radio as an advertising media. On the one hand, because it is the sound media par excellence. On the other hand, because it is where we can find the most well-known modes of audio branding such as the brand song, the jingle or the sonotype. The sample, composed of 239 inserts from the 3 generalist radio channels with the highest audiences in Spain, reveals that only $21 \%$ of items contain an element of audio branding, indicating that this is a field yet to be explored by organizations.
\end{abstract}

Keywords: audio branding; corporate communication; strategy; sonic branding; radio advertising 


\section{Resum. Identitat sonora i elements del brànding sonor a la publicitat radiofonica espanyola}

El potencial emocional que té el so és un recurs excel-lent per a les empreses i institucions que busquen testar noves vies de comunicació amb els seus públics interessats a través dels sentits. No obstant això, són encara poques les organitzacions que inclouen el so com un transmissor de la seva identitat corporativa. El brànding sonor pretén ampliar els punts de contacte amb els públics mitjançant la incorporació d'elements sonors que faciliten el reconeixement dels valors de la marca. Aquesta investigació pretén conèixer l'ús que les corporacions fan del so com a eina comunicativa i avaluar la seva presència; però, sobretot, vol esbrinar si aquest ús obeeix a un plantejament estratègic o si, al contrari, és una decisió puntual marcada per la temporalitat de les campanyes publicitàries. Per fer-ho, s'ha utilitzat la ràdio com a suport, ja que es tracta del mitjà sonor per excel-lència i on es poden localitzar les manifestacions més conegudes del brànding sonor, com la cançó de marca, el jingle o el sonotip. L'explotació de la mostra, formada per 239 insercions emeses a les tres emissores generalistes de més audiència a Espanya, revela que només el $21 \%$ de les peces conté algun element de brànding sonor. Això indica que és una àrea per explorar per part de les organitzacions.

Paraules clau: brànding sonor; comunicació corporativa; estratègia; marca sonora; publicitat radiofònica

Resumen. Identidad sonora y elementos de audiobranding en la publicidad radiofónica española

El potencial emocional que tiene el sonido es un excelente recurso para las empresas e instituciones que buscan testar nuevas vías de comunicación con sus públicos de interés a través de los sentidos. Sin embargo, son pocas todavía las organizaciones que incluyen el sonido como transmisor de su identidad corporativa. El audiobranding pretende ampliar los puntos de contacto con los públicos mediante la incorporación de elementos sonoros que faciliten el reconocimiento de los valores de la marca. Esta investigación pretende conocer el uso que las corporaciones hacen del sonido como herramienta comunicativa y evaluar su presencia, pero sobre todo quiere averiguar si dicho uso obedece a un planteamiento estratégico o si, por el contrario, es una decisión puntual marcada por la temporalidad de las campañas publicitarias. Para ello, se ha tomado como soporte la radio, ya que este es el medio sonoro por excelencia y donde se pueden localizar las manifestaciones más conocidas del audiobranding, como la canción de marca, el jingle o el sonotipo. La explotación de la muestra, compuesta por 239 inserciones emitidas en las tres emisoras generalistas de más audiencia en Espańa, revela que solo el 21\% de las piezas contiene algún elemento de audiobranding, lo que indica que es un campo por explorar por las organizaciones.

Palabras clave: audiobranding; comunicación corporativa; estrategia; marca sonora; publicidad radiofónica

\section{Introduction}

The constant search by companies and institutions for new ways to make their mark in an increasingly homogeneous and competitive market is causing a situation where "consumers are constantly being introduced to new brands" (Pathak, Calvert and Lim, 2020: 837), and so there is a powerful wide-reaching reflection emerging on the benefits that sound might bring as 
a tool for broadcasting intangibles and, consequently, as a potential ally in identification and recall processes for their products and/or services. In this context, increasing evidence shows how audio branding and its different forms contribute to building brand identities, which seem to start by making the most of the idea that "people can close their eyes but they cannot close their ears" (Chang and Chang, 2013: 7494).

There are multiple factors leading to the use of audio branding by all types of organizations. On the one hand, these factors include massive use of mobile devices by citizens, creating a vehicle for sonic connection between organizations and their audiences and forcing companies to redesign their brand communication strategies (Pedrero-Esteban, Barrios-Rubio and Medina-Ávila, 2019: 105). Furthermore, points of contact between users and brands have multiplied (Krishnan, Kellaris and Aurand, 2012: 276), in so much that the emergence of the web 2.0 and ICT development has revolutionized communication between companies and audiences (Cuevas, Sánchez and Matosas, 2019). On the other hand, other factors are emerging such as the expansion of sensory marketing and growing interest in its demonstrated advantages (Dalmoro et al., 2019; Khandelwal et al., 2020; Moral and Fernández, 2012; Ortegón-Cortázar and Gómez Rodríguez, 2016). In fact, the so-called "humanization" of companies and institutions, seeking to draw ever-closer to their users' and consumers' daily lives, is leading communication from this type of agent into the sensory field: "practitioners are now seeking ways in which to make stronger emotional connections with consumers through highly developed forms of brand communication" (Ballouli and Heere, 2015: 321).

Within this research, and in the light of what has been presented so far, audio branding is approached as a strategic instrument for comprehensive communication from organizations, meaning progress in the field of study concerning this phenomenon, given that it stands out against existing investigations into this area which approach this study matter from a purely marketing perspective (Ballouli and Heere, 2015; Chang and Chang, 2013; Gustafsson, 2015; Krishnan et al., 2014; Malenkaya and Andreyeva, 2016; Zoghaib, 2017), ignoring its potential to connect with an organization's entire audience. In the same way, this paper's originality also revolves around making radio (the sound medium par excellence), although in this case specifically radio advertising, an observatory on how sound is worked on as a strategic communication element.

\subsection{The strategic value of audio branding}

The use of sound in brand communication goes back to the origins of television advertising, with the music featuring in advertisements (Mas, Collell and Xifra, 2017). However, the potential of sound to communicate goes much further. Nowadays, we can talk about audio branding, also known as sound branding, sonic branding or acoustic branding (Gustafsson, 2015: 23), that is defined by the Audio Branding Academy (2019) as "the process of brand development 
and brand management by use of auditory elements (audio branding elements) within the framework of brand communication". As shown, this definition highlights the strategic value of this concept, in so much as it conceives it as a process which manages sound components within the framework of brand communication. This is also corroborated by Graakjær and Bonde (2018), when referring to audio branding as any sound production processes that appear continuously and consistently in relation to the brand. For this reason, when we talk about this strategic component of audio branding, we attempt to make an exhaustive observation of "our corporate identity, the exact definition of the aims of our brand and its subsequent planning within an analysis that considers the actual elements of the sound and its nature" (Vidal, 2018: 58).

While the need to stand out in an atomized market encourages organizations to promote their singularity, the strategic value of intangibles becomes essential, so that the key to differentiation lies in the actual organization, in the brand, the image or the identity (Barrio, 2018). These circumstances become more important when considering that $85 \%$ of a company's commercial value is generated from administration of immaterial, corporate goods (Brand Finance, 2019). Among them, identity is established as a fundamental intangible asset as it is expressed in "all the company's behavior and communications" (Villagra, 2015: 68). Audio branding would form part of this identity, giving meaning and recognition to the brands and/or services (Barbeito et al., 2019). Consequently, audio branding is shaped as an essential part of the brand identity which, in the words of Chang and Chang:

Represents the mission and culture of a company. (...) Corporate identity is an interdisciplinary area, including behavior and communication. Sound and visual identity can convey brand features and provide more information and communication. Certain enterprises consider sound brand as an asset. (...) Sound brand is broadly defined as using sound as part of corporate identity and conveying brand value to consumers. (2013: 7495)

\subsection{Audio branding categories}

Focusing on the different manifestations of audio branding, Bronner (2009) highlights that the most common elements of audio branding include "audio logo, jingles, brand song, brand voices, sound icon, brand landscapes and corporate anthem" (quoted by Allan, 2015: 104). Along this same line, Piñeiro-Otero (2015: 677) relates sound elements to the fields of audio branding within persuasive communication, in as much as it feeds off advertising, brand identity and branded content. Among these, Piñeiro-Otero alludes to audio logo, claim sound, brand voice, brand song and product sound. To sum up, audio branding can be presented in different ways, some more strategic and others more ephemeral.

The categorization of audio branding from papers by Audio Branding Academy (2019), Vidal (2018), Piñeiro-Otero (2015), Arichábala (2014), 
Guerra (2013), Krishnan, Kellaris and Aurand (2012), and Jackson (2003) helps determine a range of expressions that, in our opinion, make it possible to run a systematic analysis of radio advertising inserts in relation to the object of study and that can be used as a methodological basis to exploit the results obtained in this research. Consequently, and as a result of reviewing the aforementioned papers, the following classification is proposed:
a) Audio logo
b) Claim sound
c) Commercial song
d) Jingle
e) Brand song
f) Brand voice
g) Product sound

a) Audio logo: is the brand's sonic identity. Its mission is to identify the brand using sounds. It must be brief, memorable and coherent. It is possible to differentiate between logos using vocals, sound effects, musical compositions (instrumental or sung) or any others that include music and voice in a short period of time. As mentioned by Vidal (2018: 68) "this is the sonic equivalent of a logo in terms of the representative function of its visual identity," and its main function consists of identifying the broadcasting brand in just a few notes. In short, the audio logo is established as the main sound component identifying a brand, emphasizing its strategic nature in corporate brand management. One good example of an audio logo is the melody for "Always Coca-Cola" (Ballouli and Heere, 2015: 323).

b) Claim sound: is a sound item similar to the audio logo although distinguished by expressing a key message (claim). Normally it consists of a short song describing the main attributes of the product or service on offer (Piñeiro-Otero, 2015: 670). One example of this comes from the Carglass brand, a company specializing in repair and replacement of car windscreens, with its popular claim in Spanish radio advertising "Carglass cambia, Carglass repara" (Carglass changes, Carglass repairs).

c) Commercial song: is the song or melody that is used in advertising campaigns. While that campaign lasts, this song or melody is selected as a communication element, although without determining its strategic role in generating corporate branding. According to the Audio Branding Academy, it is the music that is used "as spot background and background music and - as opposed to brand song (q.v.) - is employed only temporarily or just once in an advertising campaign" (2019). This format is therefore characterized by being part of a certain campaign and lasts for a limited time, which is why we refer to it as ephemeral.

d) Jingle: is the sung version of the advertisement. It consists of a brief song or melody that is easy to remember, created specifically for the brand. Its customized composition makes these messages easier to identify and 
remember (Lusensky, 2010). One example is the Kit Kat advert from the 1980 s with the song "Give Me A Break".

e) Brand song: is a piece of music in the form of a song that expresses the sonic identity of the corporate brand. It is an ad hoc composition for the organization and attempts to communicate its values. It is directly related to the corporate brand strategy, so it must match the actual organization's characteristics and it might be instrumental or sung (Piñeiro-Otero, 2015). As opposed to the commercial song and the jingle, the brand song is used over a long period of time (Ballouli and Heere, 2015), and as stated by Vidal (2018), it represents a new scenario that "aims to tie in the audience with the brand, beyond its products" (2018: 65-66). One example of a brand song is the tune for Twenty Century Fox.

f) Brand voice: vocal element used to communicate brand personality orally. Its sound evokes its values and identity. As defined by the Audio Branding Academy, this is a vocal element of brand communication that "represents the brand personality and is often part of an audio logo" (Audio Branding Academy, 2019). It can be present in the actual audio logo and in the advertising creativities and "numerous brands use the specific voice of a spokesperson to represent themselves, sometimes for years and across multiple channels" (Zoghaib, 2017: 492).

g) Product sound: is the sound that forms part of the product identity and that is usually recognized by the consumer. "The click of the iPhone camera (DeWitt and Bresin, 2007), closing the door of a Volkswagen (Filipou et al., 2003; Humphreys et al., 2011), or the pop of a tube of Pringles (Spence, 2014) form part of the product and brand identity" (Piñeiro-Otero, 2015: 671).

In terms of categorizing the different audio branding modes presented here, it is important to highlight any longer-lasting, strategic components accompanying the corporate brand over the years, including the audio logo, the brand voice and the brand song. On the contrary, the commercial song is a more ephemeral item, not as closely tied to the corporate brand.

It is clear that this audio branding classification does not exclude other forms that, although not worth considering within the framework of radio advertising inserts, do appear in other contexts of communication. These include the brand soundscape, that is the sound theme used on websites, sales points, videos, call-waiting, etc. and the corporate podcast that, like the others, becomes an anchoring point for identifying, recognizing and building the brand identity (Barbeito and Perona, 2019).

\subsection{Audio branding and economic sectors}

Audio branding is an element of corporate identity (Jackson, 2003) with great potential that is already being applied in different economic sectors. Currently, "a wide range of industries are using sonic branding strategies" (Gustafsson, 2015: 21). However, it should be expected that, in the same 
way as each economic or industrial sector presents specific trends when working on its brands and/or services, the use of audio branding will also vary by sector. Proof of this is the publication by Flyabit (2013), which revealed at the time that, when studied by sector, technology (Nokia, Apple, Windows) was the sector that used audio branding most often, whilst also demonstrating that companies investing in it achieved better brand recall and saved 70\% in musical copyright costs in the medium term.

A subsequent project, the Audio Logic Index drawn up by Veritonic (2019), presents a ranking relative to the main manifestations of audio branding - the audio logo or sonotype - with the greatest repercussion in the United States and the United Kingdom. The ranking was drawn up using a survey among over 1600 panelists in these countries who were asked to record their emotions as sounds were played. This also included questions on other feelings and associations that were evoked by audio logos, even the brands that these sounds elicited. Finally, subjects were contacted 48 hours after listening to measure their recall. The results from this analysis provide a ranking of the economic sectors with the highest use of this instrument. In the case of the United States, financial services (including insurance companies and banks) and automotive components hold the top spots, while in the United Kingdom these positions were held by fast food and technology. The travel sector highlights a remarkable difference between the two countries as, despite scoring well in the United Kingdom, it stands last in the United States' classification on audio branding in their communication actions.

Figure 1. Ranking of sectors with best use of audio logos

Overall score by industry

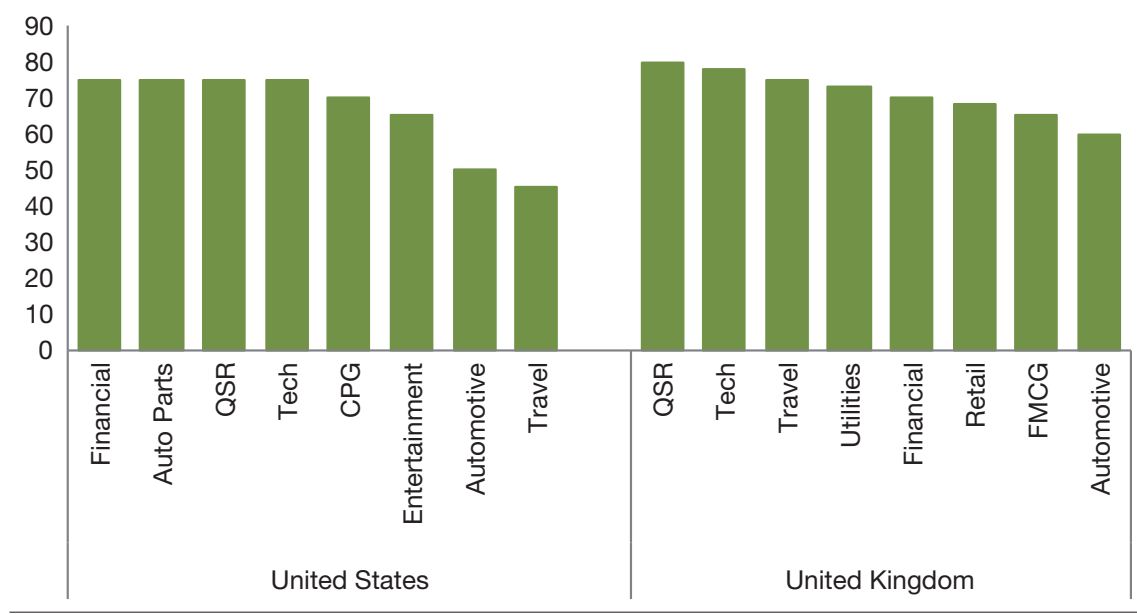

Source: Own work drawn up from the Veritonic data (2019: 7). 


\section{Aims and methodology}

Audio branding makes it possible to understand how the different sounds proposed by organizations in their communication must follow a coherent plan, previously determined from what the company represents and how it wants to be perceived, so that sound also becomes an element to be considered when building a brand, Nevertheless, sonic melting pots have existed for many decades. Radio has been a traditional platform for brands to make themselves heard. In Spain, jingles from some corporations are well known and have become part of the collective memory; likewise voices of broadcasters who are automatically identified with the company or the institution that they represent. All this has materialized in the form of microspaces or mentions that have moved beyond promotion of the actual products to become sound profiles. It has also been seen how, through sponsorship, organizations have entered thousands of homes via radio-theatre programs. This explains why, in our case, we have chosen to go back to the beginning to select the sample and propose observing audio branding expressions that organizations use in an exclusively audio advertising medium such as radio to reach out to its external audiences (consumers, potential consumers, users and citizens in general, among others).

The main purpose of this study is, therefore, to answer the following questions:

Q1: What is the presence of audio branding elements in Spanish radio advertising?

Q2: Which sectors show a greater inclination to include audio branding in communication with audiences over the radio?

Q3: Which audio branding categories are most used by organizations in their radio advertising?

Q4: How far does the economic sector determine the use of the different audio branding categories, in other words, is there any type of category/sector correlation?

The methodological criteria to obtain the sample to be analyzed, working from the questions devised, were as follows:

1. Selection of the three generalist Spanish radio channels with the greatest audience that feature advertising, namely, Cadena SER, Cope and Onda Cero.

2. Sizing the sample, considering the time frame for maximum radio audiences. This referenced the radio audience data presented in the AIMC General Framework for the Media in Spain report (2019). Consequently, the time frame selected to obtain this sample is between 9 am and 12 noon.

3. Simultaneous observation in one day, carried out during the week of 4th to 10th February 2019. As a result, 239 units of analysis were obtained, which were categorized according to the following variables: 
advertiser, brand, product, economic sector, use of audio branding and elements of audio branding used.

4. Classification of economic sectors referencing the sector-based classification provided by Infoadex (Table 1).

Table 1. Classification of economic sectors

\begin{tabular}{lll}
\hline 1. Automotive & 8. Food & 17. Textile and clothing \\
2. Distribution and catering & 9. Transport, travel and tourism & 18. Personal objects \\
3. Finance, insurance and & 10. Beverages & 19. Cleaning \\
consultancy & 11. Gambling and betting & 20. Industrial, work material \\
4. Culture, teaching and the & 12. Health & and agro-fishing \\
media & 13. Sports and leisure & 21. Office equipment and \\
5. Beauty and hygiene & 14. Home & business \\
6. Public and private services & 15. Energy & 22. Tobacco \\
7. Telecommunications and the & 16. Construction and estate & 23. NGOs and foundations \\
internet & agents & 24. Misc.
\end{tabular}

Source: Own work based on Infoadex (2019).

\section{Results}

The presence of audio branding elements in Spanish radio advertising is relatively low, so much so that in the light of these research results, only $21 \%$ of the inserts in the sample include an expression of audio branding. Consequently, and in answer to the first of the questions raised (Q1), it can be stated that, in the case of Spain, one fifth of organizations that advertise on the radio include some expression of audio branding in their advertising on this medium.

Regarding Q2, on the presence of audio branding depending on the different economic sectors, the analysis demonstrates that sectors such as beauty and hygiene; energy; personal objects; cleaning; industrial; work material and agro-fishing and tobacco are not advertised on the radio. Therefore, study

Figure 2. Presence of audio branding

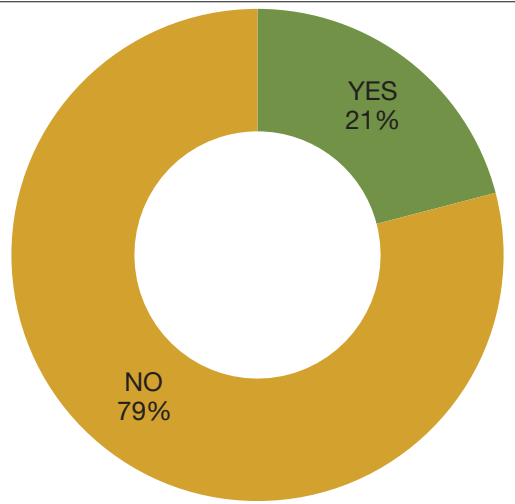

Source: Own work. 
inserts will comprise the following sector-based categories: automotive; distribution and catering; finance, insurance and consultancy; culture, teaching and the media; public and private services; telecommunications and the internet; food; transport, travel and tourism; beverages, gambling and betting; health; sports and leisure; home; construction and estate agents; textile and clothing; office equipment and business, NGOs and Foundations and miscellaneous.

The data obtained show that the sector that most includes audio branding elements is telecommunications and the internet, as this appears in 88\% of its radio advertisements. It is followed by home, with use of audio branding in $71 \%$ of cases. Food lies in third place. This sector includes some sonic identity tools in half of its inserts.

These data demonstrate a clear correspondence with the results presented by Flyabit in 2013, particularly referring to telecommunications and the internet. Back then, the technology sector already seemed to be the most likely to use audio branding in its communication actions. On the other hand, if you relate these results to the Veritonic (2019) project that analyses performance in the use of the audio logo in the United States and the United Kingdom, technology once again holds top positions, demonstrating that this is a sector that trusts audio branding as a strategic instrument for interacting with its audiences. Quite the opposite happens with the automotive sector, which only includes it in $13 \%$ of the advertising inserts analyzed, something that also coincides with the Veritonic study (2019), revealing it to be a commercial field with low use of audio logos in the United States.

Having detected the sectors that include an audio branding component in their radio advertising, the next step is to find out which elements they use

Figure 3. Ranking of the 10 sectors that use audio branding

\section{Percentage of advertising insertions with audio branding} of the total insertions in each sector

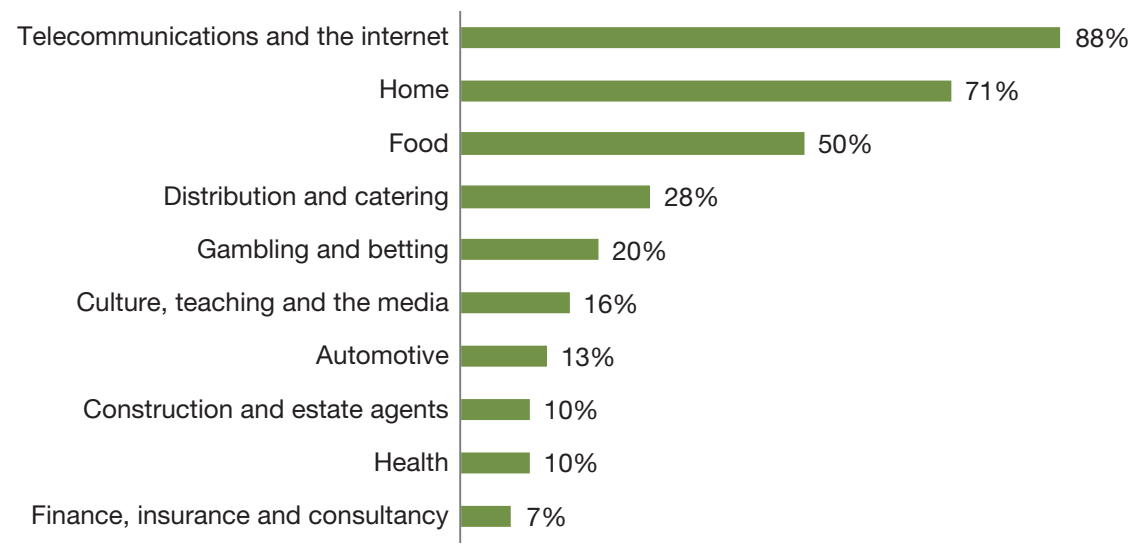


(Q3). The result show that commercial song is the category with the most presence $(44 \%)$ as shown in Figure 4. It should be highlighted that this type is curiously the most ephemeral, bound to a product or specific advertising campaign, and the furthest from the corporate brand and a long term brand strategy because, as previously mentioned, it is related to specific creative performance. However, the audio logo, one of the items that most represents the brand identity, only appears in $12 \%$ of the units of analysis. A priori, in the light of these results, it might seem that the organizations favor one-off, non-strategic sound elements, although the appearance of the brand song in $30 \%$ of cases partially counters this idea.

Figure 4. Type of audio branding used in advertising inserts

Audio branding categories used

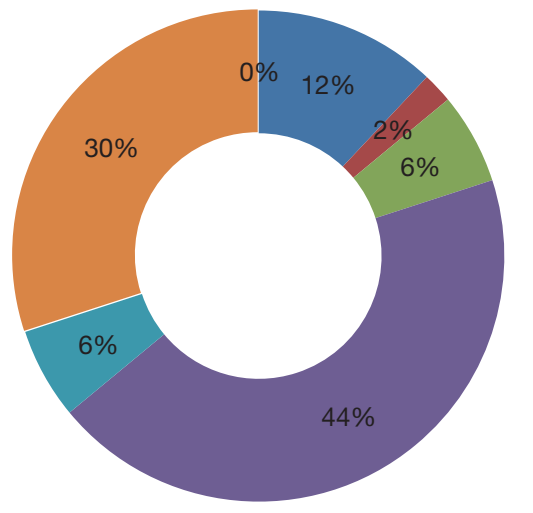

Audio logo

Claim sound

Brand voice

Commercial song

Jingle

Brand song

Product sound

Source: Own work.

The last step to satisfy the initial approach of this analysis proposal is to observe whether there is a relationship between the uses of the audio branding elements and the economic sector that uses them (Q4). In other words, whether the type of advertiser conditions the choice of audio branding identity tools. From the data presented in table 2, we can extract the following results.

The home sector shows the most diversification in the use of audio branding tools, as it appears in the top positions in the audio logo, jingle, brand voice and brand song categories. Along this line, telecommunications and the internet lies second, present in three categories (audio logo, commercial song and brand song), whilst third place sectors are food, which uses audio logo and claim sound, and culture, teaching and the media, featuring brand voice and commercial song.

If we look at the most popular options, $82 \%$ of inserts that include a commercial song are split between 3 economic sectors: culture, teaching and 
the media (32\%), distribution and catering (27\%) and telecommunications and the internet $(23 \%)$. For the brand song, it is doubtlessly most noteworthy that $67 \%$ of presence refers to products related to the home, followed by health, a long way behind with $13 \%$. Finally, regarding the presence of the audio logo, more than half is divided between the home and food sectors $(66 \%)$ and the rest, in equal proportions $(17 \%)$ telecommunications and the internet, insurance and consultancy.

From the tools categorized as audio branding elements, the scarcest manifestations in our research are the claim sound (2\%), jingle (6\%) and brand voice $(6 \%)$. In the case of the jingle or the commercial song, the sectors that include it are home, with $67 \%$ and construction and estate agents, with 33\%. The use of voice as a brand identity instrument (brand voice) is accumulated by culture, teaching and the media, as this sector represents $67 \%$ of the total use of the brand voice, followed by home (33\%).

Finally, the last element of audio branding that is represented in the data analyzed is the claim sound, represented by a single proposal from the food sector.

From the data, it can also be seen that the commercial field that most believes in the strategic value of sound as a tool to build the brand is home, as it is the sector with the most presence in the use of elements such as the audio logo and brand song.

Table 2. Percentage use of the different forms of audio branding depending on the economic sector

\begin{tabular}{lc}
\hline \multicolumn{2}{c}{ Audio logo } \\
\hline Home & $33 \%$ \\
Food & $33 \%$ \\
Telecommunications and the internet & $17 \%$ \\
Finance, insurance and consultancy & $17 \%$ \\
\hline \multicolumn{2}{c}{ Commercial song } \\
\hline Culture, teaching and the media & $32 \%$ \\
Distribution and catering & $27 \%$ \\
Telecommunications and the internet & $23 \%$ \\
Gambling and betting & $9 \%$ \\
Automotive & $4.5 \%$ \\
Finance, insurance and consultancy & $4.5 \%$ \\
\hline
\end{tabular}

Product sound

\begin{tabular}{|c|c|}
\hline \multicolumn{2}{|l|}{ Claim sound } \\
\hline Food & $100 \%$ \\
\hline \multicolumn{2}{|l|}{ Jingle } \\
\hline Home & $67 \%$ \\
\hline Construction and estate agents & $33 \%$ \\
\hline \multicolumn{2}{|l|}{ Brand voice } \\
\hline Culture, teaching and the media & $67 \%$ \\
\hline Home & $33 \%$ \\
\hline \multicolumn{2}{|l|}{ Brand song } \\
\hline Home & $67 \%$ \\
\hline Health & $13 \%$ \\
\hline Distribution and catering & $13 \%$ \\
\hline Telecommunications and the internet & $7 \%$ \\
\hline
\end{tabular}

0 inserts

Source: Own work.

\section{Conclusions}

Today's dominant business dynamics emphasize that companies are no longer differentiated by the physical attributes of the products or services that they offer, but rather more by intangible values including identity and cor- 
porate brand. It is precisely in this context that audio branding might become an identifying sound instrument with great potential that provides meaning and recognition to all types of organizations, both companies and institutions.

Increasing awareness concerning climate change and emergency has led many governments, administrations, companies and individuals to employ measures to reduce our negative impact on the planet. They are keen to reduce all types of pollution: atmospheric, water, light, noise, etc. The automotive sector, for example, is changing its business model by redefining itself as an electric model. In an environment that is embracing silence, brands can find fertile ground to summon their own voice to express their identity and their personality; in short, to equip themselves with elements of audio branding. This, along with other factors such as the growing use of digital devices, an increase in points of contact between the company and their audiences or the expansion of sensory marketing, makes audio branding an essential work area.

Audio branding comes in many forms such as the audio logo, claim sound, commercial song, jingle, brand song, brand voice and product sound. Out of them all, the audio logo and the brand song stand out as the most strategic identifying sound elements that accompany the corporate brand over the years. On the contrary, the commercial song is a more ephemeral element belonging to a specific commercial campaign and related directly to the product or service being advertised and not to the actual corporate brand.

In relation to the expressions of audio branding in Spanish radio advertising, the following conclusions can be drawn.

Audio branding is used in $21 \%$ of radio advertising items, meaning that there is still a long way to go in this matter if it is to fulfil its potential. Considering that advertising communication actions are currently carried out work from the concept of a holistic vision and usually involve $360^{\circ}$ actions, it can be stated that few corporations are currently using audio branding as a strategic instrument for their brand.

There is particular backing for audio branding in the commercial song category. This is a further indication that in the case of Spanish radio advertising, audio branding is still not considered to be a completely strategic element for organizations, as it prioritizes the commercial song over other more corporate elements, that might represent the brand comprehensively and over a long period of time such as the audio logo or the brand song. Therefore, from the point of view of comprehensive communication, it might be concluded that communication focusing on elements within the product's closer orbit prevails over corporate communication. Even so, use of the brand song should be highlighted in $30 \%$ of the items analyzed with audio branding.

The sector that most backs the use of audio branding in Spain is telecommunications and the internet. As mentioned previously, this result matches data presented in previous analyses (Flyabit, 2013; Veritonic, 2019), pro- 
duced both nationally and internationally (UK and US). The creation and incorporation of voice assistants such as Google Assistant, Alexa from Amazon, Siri from Apple, Cortana from Microsoft or Bixby by Samsung as part of our daily lives has given sound a new lease of life and its different components (voice, music, effects) are once again brought to the fore. This revival of sound, also bound to the emergence of sensory and experience-related marketing, is doubtlessly a good omen for the future of audio branding. Sound seems as though it is back to stay, if it ever went away at all.

Sectors that most stand out in strategic use of audio branding, applying manifestations such as the audio logo and the brand song are home, food and telecommunications and the internet. Therefore, we can once again state that telecommunications and the internet is a sector that is highly aware of the use of audio branding.

In Spain, radio has always been considered a complementary medium in advertisers' media strategies. Consequently, the data obtained in this research on audio branding in radio advertising cannot be extrapolated to the rest of the media as the number of advertisers and sectors present in each medium differs according to the communicative strategies and specific aims of each campaign. Although it is true that, as we have just mentioned, the data cannot be extrapolated to other media, we can nevertheless infer extrapolation to activity sectors involving advertising via other media. In other words, the sectors in this study that include elements of audio branding in their radio advertising will also use the elements mentioned here, as a minimum, when advertising on television, in the cinema or on the internet. The reason is twofold. On the one hand, the radio's subsidiary role means that radio advertising items are taken from the audio in audiovisual items (most usually advertisements) or, in the best cases, adapted. On the other hand, the need to express the same concept to give the campaign some coherence so that the target, independently of the medium or support through which they are accessing the communicative action, receives and understands the same idea, means that certain elements have to be maintained (tone, style, etc.) when performing any of these actions. In any case, there is no doubt that the sound elements provide consistency in any type of communicative manifestation that the organization initiates to connect with its audience.

To sum up, the search for exclusivity in the market, the approach to the sensory field and the digital world are encouraging corporations to consider audio branding in their communication strategies. The use of one audio branding proposal or another and the way of working each of them will be what makes audio branding a real strategic component of the corporate identity and brand or, on the other hand, a simple ephemeral optional that is more tightly bound to an advertising campaign than to the actual organization. 


\section{Bibliographical references}

Allan, D. (2015). "Audiobranding an ROI-A review”. In: Audio Branding Yearbook 2014/2015. Baden-Baden: ABA. Nomos Edition. <https://doi.org/10.5771/9783845260815-103>

ARICHÁBALA, J. K. (2014). Estudio de audio-branding, construcción de una marca: caso aplicado a un nuevo producto en la ciudad de Azogues para el 2014. Cuenca: Universidad de Cuenca (Ecuador). Retrieved January 23, 2020, from <http:// dspace.ucuenca.edu.ec/bitstream/123456789/21215/1/Tesis.pdf>.

Audio Branding ACADEMY (2019). Glossary. Retrieved October 22, 2019, from $<$ https://audio-branding-academy.org/knowledge/glossary/>.

Ballouli, K. and HeEre, B. (2015). "Sonic branding in sport: A model for communicating brand identity through musical fit". Sport Management Review, 18 (3), 321-330. <https://doi.org/10.1016/j.smr.2014.03.001>

Barbeito, M. L., Barrio, E., Enrique, A. M., Fajula, A. and Perona, J. J. (2019). "La marca que se escucha: estrategias sonoras en el branding de las insti-

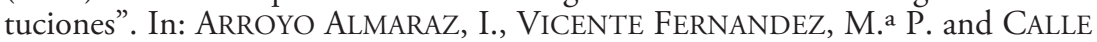
MENDOZA, S. (coords.). Las herramientas digitales en la comunicación social. Madrid: Fragua, 55-71.

BARbeito, M. L. and Perona, J. J. (2019). "Comunicación organizacional en clave sonora: el caso de Blink, los podcasts de BBVA". El profesional de la información, 28 (5), 1-9. <https://doi.org/10.3145/epi.2019.sep.11>

BARRIO, E. (2018). "La gestión de la responsabilidad social corporativa: Propuesta de un modelo teórico”. Questiones Publicitarias, 1 (22), 59-68. $<$ https://doi.org/10.5565/rev/qp.311>

BRAND FINANCE (2019). Global Intangible Finance Tracker. Retrieved January 23, 2020, from <https://brandfinance.com/images/upload/gift_2.pdf>.

CHAnG, W. L. and Chang, Y. T. (2013). "Exploring the path from sound to brand on customer intention". International Information Institute Ltd., 16 (10), 74937505.

Cuevas, E., SÁnChez, M. and Matosas, L. (2019). "Bibliometric analysis of studies of brand content strategy within social media”. Comunicacion y Sociedad (Mexico), 2019(e7441), 1-25. <https://doi.org/10.32870/cys.v2019i0.7441>

Dalmoro, M., Isabella, G., Almeida, S. O. de and dos Santos Fleck, J. P. (2019). "Developing a holistic understanding of consumers' experiences: An integrative analysis of objective and subjective elements in physical retail purchases". European Journal of Marketing, 53 (10), 2054-2079. <https://doi.org/10.1108/EJM-10-2016-0586>

FLYABIT (2013). I Estudio Flyabit Audio Branding España. Flyabit Audio Branding Studio

GRAAKJÆR, N. J. and BONDE, A. (2018). "Non-musical sound branding - a conceptualization and research overview". European Journal of Marketing, 52 (7/8), 1505-1525. <https://doi.org/10.1108/EJM-09-2017-0609>

Guerra, G. (2013). Music Branding, qual é o som da sua marca? Rio de Janeiro: Elsevier. 
Gustafsson, C. (2015). "Sonic branding: A consumer-oriented literature review". Journal of Brand Management, 22 (1), 20-37. <https://doi.org/10.1057/bm.2015.5>

INFOADEX (20 de febrero de 2019). Estudio InfoAdex de la Inversión Publicitaria en España 2019. Recuperado el 19 de septiembre de 2019 de <https://www.infoadex. es/home/estudio-infoadex-de-la-inversion-publicitaria-en-espana-2019/>.

JACKSON, D. (2003). Sonic Branding. New York: Palgrave Macmillan. <https://doi.org/10.1057/9780230503267>

Khandelwal, M., Sharma, A., Indoria, V. and Jain, V. (2020). "Sensory marketing: an innovative marketing strategy to sustain in emerging markets". International Journal of Public Sector Performance Management, 6 (2), 236-245. $<$ https://doi.org/10.1504/IJPSPM.2020.106730>

Krishnan, V., Kellaris, J. J. and Aurand, T. W. (2012). "Sonic logos: can sound influence willingness to pay?”. Journal of Product \& Brand Management, 21 (4), 275-284. <https://doi.org/10.1108/10610421211246685>

Krishnan, V., A. Machleit, K., J. Kellaris, J., Y. Sullivan, U. and W. AURAND, T. (2014). "Musical intelligence: explication, measurement, and implications for consumer behavior". Journal of Consumer Marketing, 31 (4), 278-289. <https://doi.org/10.1108/JCM-01-2014-0843>

LUSENSKY, J. (2010). Sounds like branding. Sweden: Heartbeats International.

Malenkaya, Y. and AndreyeVA, A. (2016). "Fashion and audio branding: The analysis and interpretation of luxury fashion marketing concepts". Journal of Global Fashion Marketing, 7 (4), 291-304. <https://doi.org/10.1080/20932685.2016.1198238>

Mas, L., Collell, M.-R. and Xifra, J. (2017). "The Sound of Music or the History of Trump and Clinton Family Singers: Music Branding as Communication Strategy in 2016 Presidential Campaign”. American Behavioral Scientist, 61 (6), 584-599. <https://doi.org/10.1177/0002764217701214>

Moral, M. and Fernández Alles, M. T. (2012). "Nuevas tendencias del marketing: el marketing experiencial”. Entelequia. Revista Interdisciplinar, 14, 237-251. Retrieved from <https://revistaentelequia.wordpress.com/2012/05/01/nuevastendencias-del-marketing-el-marketing-experiencial/>.

Ortegón-Cortázar, L. and Gómez Rodríguez, A. (2016). "Gestión del marketing sensorial sobre la experiencia del consumidor". Revista de Ciencias Sociales, XXII (3), 67-83.

Pathak, A., Calvert, G. A. and Lim, L. K. S. (2020). "Harsh voices, sound branding: How voiced consonants in a brand's name can alter its perceived attributes". Psychology \& Marketing, 37 (6), 837-847. <https://doi.org/10.1002/mar.21346>

Pedrero-Esteban, L. M., Barrios-Rubio, A. and Medina-Ávila, V. (2019). "Teenagers, smartphones and digital audio consumption in the age of Spotify". Comunicar, 27 (60), 103-112. <https://doi.org/10.3916/C60-2019-10>

PiñeIro-OTERo, T. (2015). "From jingle to corporate radios. An approach to audio branding concept”. Prisma Social, 14, 663-688. Retrieved October 10, 2019, from <https://www.isdfundacion.org/publicaciones/revista/numeros/14/ secciones/abierta/nbiblio_01_jingle_radios.html $>$. 
VERITONIC (2019). Audio Logo Index 2019. The Ranking of Sonic Branding Effectiveness.

VIDAL, M. (2018). Branding Sonoro Sonokey. El método de impulso emocional y mnemotécnico para las marcas. Barcelona: Editorial UOC.

Villagra, N. (2015). "La gestión de intangibles y la dirección de comunicación”. In: A. M. EnRIQUE and F. MORALES (Eds.). Somos estrategas. Dirección de Comunicación Empresarial e Institucional. Barcelona: Gedisa, 61-84.

ZOGHAIB, A. (2017). "The contribution of a brand spokesperson's voice to consumer-based brand equity". Journal of Product \& Brand Management, 26 (5), $492-$ 502 .

<https://doi.org/10.1108/JPBM-06-2016-1230> 
